\title{
PRODUKSI UMPAN RAYAP DARI LIMBAH BAHAN ORGANIK DAN EFEKTIVITASNYA DALAM PENGENDALIAN SERANGAN Coptotermes sp.
}

\author{
Termite Bait Production from Organic Waste Masterials and Its Effectiveness in Controlling Coptotermes sp. \\ Agung Nugrawan Kutana ${ }^{1 凶}$, Musrizal Muin², Astuti Arif² \\ 1 Undergraduate Student, Forest Products Utilization and Processing Laboratory, Hasanuddin University, Makassar \\ 2Lecturer, Forestry Faculty, Hasanuddin University, Makassar Jl.Perintis Kemerdekaan Km.10. Makassar \\ corresponding author: agung151097@gmail.com
}

\begin{abstract}
Damages of building construction due to termite attacks have caused high economic losses and therefore, efforts are continuously developed to overcome the serious problem. Baiting system is one way to control termite attacks as it consists of acceptable termite food sources, combined with a slow-acting substance lethal to termites. This study was conducted to produce termite bait materials from organic waste mixtures and evaluate its effectiveness against termite attacks in the field. The termite baits were produced by mixing paper, cardboard, and degraded pine wood, combined with leaves of Melaleuca leucadendron Linn assumed to be toxic to termites. Tapioca starch was used as glue and added to the organic materials mixture before pressed at room temperature with the target density of $1.0 \mathrm{~g} / \mathrm{cm}^{3}$. The produced baits were placed in the field with signs of heavy attacks of termites, Coptotermes sp., and observed every three days for the termite elimination. Results showed that the bait formulation enables to significantly eliminate the termite attacks with high attractant properties. However, its effectiveness was still lower than the commercial bait due to its high capacity of water absorption, indicating the importance of further research on its mixture and glue formulation.
\end{abstract}

Key words: Bait formulation; Coptotermes sp.; Organic Waste Materials; Melaleuca leucadendron

\section{A. PENDAHULUAN}

Rayap tanah (subterannean termites) merupakan organisme perusak kayu dan bangunan yang sangat berperan penting terutama di daerah tropis. Secara ekonomi, kerugian yang disebabkan oleh rayap ini terus mengalami peningkatan. Data menunjukkan bahwa kerugian akibat serangan rayap mencapai Rp. 3,73 triliun di tahun 2000 (Nandika, dkk., 2003) dan terus mengalami peningkatan pada angka sebesar Rp. 8,68 triliun di tahun 2015 (Lesmana, 2015). Kerugian tersebut tentu saja tidak sedikit, sehingga diperlukan upaya-upaya untuk menekan laju kerugian yang disebabkan oleh aktivitas rayap ini, khususnya yang secara spesifik melakukan serangan pada bangunan ataupun konstruksi yang terbuat dari kayu. Hal ini juga berdampak pada metode dalam pengendalian rayap yang terus mengalami perkembangan.

Salah satu metode alternatif pengendalian rayap yang saat ini cukup berkembang adalah pengumpanan (baiting), yaitu pengendalian rayap dengan menggunakan formulasi umpan. Prinsip dasar dari metode ini adalah dengan memanfaatkan sifat tropalaksis dari rayap yaitu saling memberi makanan terhadap anggota rayap lain (Tambunan dan Nandika, 1989) dimana rayap pekerja akan memakan bahan umpan yang beracun dan disebar ke dalam koloni. Oleh sebab itu, bahan aktif dari racun untuk digunakan bersama umpan harus bersifat slow action agar rayap pekerja masih bisa menyebarkan makanannnya ke seluruh koloni rayap. Salah satu bahan aktif yang bersifat dapat mematikan rayap yang telah diteliti oleh Indrayani, dkk. (2016) adalah sineol, melaleucin, minyak atsiri yang terdiri dari terpineol, cineol dan lignin yang terdapat pada daun kayu putih (Melaleuca leucadendron Linn.).

Sistem umpan dinilai sangat efisien dalam pengendalian rayap secara berkoloni. Kelebihan metode sudah dibuktikan dengan berbagai penelitian dan sudah diterima sebagai metode pengendalian rayap di Amerika Utara, Hawaii dan berbagai wilayah lainnya (Grace dan Su, 2001). Teknik pengumpanan lebih efektif dibanding dengan teknik penyemprotan langsung terhadap tanah atau tempat koloni rayap (Sucipto, 2009). Pernyataan ini diperkuat oleh hasil penelitian Djunaedy (2007) yang memperlihatkan nilai mortalitas rayap yang lebih tinggi pada teknik pengumpanan dibandingkan dengan teknik penyemprotan. Bentuk pengendalian ini bersifat lebih ramah lingkungan, karena target umumnya bersifat spesifik. Dalam hal ini, insektisida yang digunakan dikemas dalam umpan makanan yang disenangi rayap (Iswanto, 2005). Namun, umpan rayap yang digunakan selama ini menggunakan proses produksi dan bahan yang biayanya sangat mahal. Salah satu usaha untuk 
mengatasi permasalahan tersebut dengan dilakukannya pengumpanan dengan menggunakan bahan dari limbah organik seperti limbah kayu yang terdegradasi, limbah kertas dan kardus (Muin, dkk., 2014). Meskipun demikian, penelitian tersebut masih dalam skala laboratorium dengan menggunakan sampel yang dibuat secara manual. Pembuatan sampel secara manual tidak mampu menghasilkan umpan dengan kerapatan tinggi seperti umpan pada umumnya yang tersedia secara komersil dengan standar kerapatan sekitar 1,5 gram cm-3. Oleh karena itu, penelitian ini perlu dilakukan untuk mendukung dalam pengembangan teknologi produksi umpan dan pengujian efektivitasnya di lapang.

Tujuan penelitian ini adalah untuk menemukan teknologi produksi umpan dari limbah bahan organik dan mengevaluasi efektivitasnya dalam pengendalian serangan rayap di lapang. Penelitian ini diharapkan menjadi landasan dalam pengembangan teknologi produksi formulasi umpan dari limbah bahan organik.

\section{B. METODE PENELITIAN}

\section{Waktu dan Tempat}

Penelitian ini dilaksanakan pada bulan Februari-Juni 2018, dengan tahapan pembuatan contoh uji dilaksanakan di Unit Penggergajian dan Pengerjaan Kayu, Laboratorium Pemanfaatan dan Pengolahan Hasil Hutan, Fakultas Kehutanan, Universitas Hasanuddin; dan pengujian lapangan dilaksanakan di lokasi Perumahan Dosen Universitas Hasanuddin, Tamalanrea, Makassar.

\section{Alat dan Bahan}

Alat yang digunakan adalah timbangan digital, pipa, cetakan umpan, hammer mill, alat kempa, gergaji dan termite baiting. Bahan yang digunakan adalah kayu pinus lapuk (Pinus merkusii Jungh et de Vriese), limbah kertas HVS dan kardus, daun kayu putih (Melaleuca leucadendron Linn.), umpan komersil dan tepung tapioka.

\section{Prosedur Kerja}

\section{Persiapan Bahan}

Bahan-bahan yang akan digunakan dalam pembuatan umpan adalah kayu pinus lapuk, limbah kertas HVS dan kertas kardus, dan daun kayu putih. Kayu pinus lapuk diambil dari Hutan Tanaman Pinus di Hutan Pendidikan Universitas Hasanuddin Kabupaten Maros. Limbah kertas HVS dan kertas kardus diambil dari tempat penumpukan dan penimbangan kertas bekas. Kayu putih diambil dari Kabupaten Pontianak Kalimantan Barat. Bahan dasar umpan tersebut dipersiapkan dalam kondisi kering udara dengan mencampurkan semua bahan dengan perbandingan 1:1:1:2, kemudian dihancurkan dengan menggunakan hammer mill. Formulasi bahan umpan ini dibuat berdasarkan hasil penelitian sebelumnya (Indrayani, dkk., 2016).

\section{Proses Produksi}

Bahan sampel umpan dibuat dengan teknik pembuatan papan komposit dengan target kerapatan \pm 1 $\mathrm{gram} \mathrm{cm}^{-3}$. Untuk pembuatan sampel tersebut digunakan tepung tapioka sebagai perekat dengan cara diencerkan dengan perbandingan $5 \mathrm{gram}$ tapioka dalam $50 \mathrm{ml}$ air (Mahathir, 2014). Campuran bahan umpan selanjutnya dimasukkan ke dalam cetakan berukuran $28 \mathrm{~cm} \times 28 \mathrm{~cm} \times$ $1 \mathrm{~cm}$, kemudian dikempa pada suhu kamar. Kerapatan ditentukan dengan formulasi sesuai dengan SNI 01-44492006 sebagai berikut:

$\operatorname{Kerapatan}\left(\mathrm{g} / \mathrm{cm}^{3}\right)=\frac{\mathrm{B}}{\mathrm{V}}$

dimana: $B$ adalah berat $(\mathrm{g}), \mathrm{V}$ adalah volume $\left(\mathrm{cm}^{3}\right)$ : panjang $(\mathrm{cm}) \times$ lebar $(\mathrm{cm}) \times$ tebal $(\mathrm{cm})$

\section{Pembuatan Sampel Uji}

Sampel uji yang dipersiapkan untuk penelitian ini adalah sampel uji berupa umpan yang berasal dari hasil pengempaan, lalu dipotong dengan ukuran $18 \mathrm{~cm} \times 3 \mathrm{~cm}$ $\mathrm{x} 1 \mathrm{~cm}$ sebelum diuji di lapangan.

\section{Penentuan Lokasi Pengujian Lapangan}

Penentuan lokasi penelitian menggunakan metode purposive sampling. Lokasi pengujian yang dipilih untuk mengetahui efektivitas sampel uji adalah tempat yang diketahui memiliki aktivitas serangan rayap. Hasil pengamatan awal menunjukkan adanya aktivitas rayap di Perumahan Dosen Universitas Hasanuddin, Tamalanrea, Makassar. Oleh karena itu, lokasi tersebut dipilih untuk mencapai tujuan penelitian ini.

\section{Pelaksanaan Pengujian Lapangan}

Uji lapangan dilakukan untuk mengetahui persentase pengurangan jumlah anggota koloni rayap yang menyerang sampel umpan dengan membandingkannya dengan umpan komersil. Pengujian sampel uji di lapangan dilakukan dengan tahapan sebagai berikut:

a. Sebanyak 5 stasiun ditanam dan disebar di lokasi penelitian dengan jarak setiap stasiun yaitu $1 \mathrm{~m}$ untuk mengetahui adanya aktivitas rayap.

b. Sampel uji dimasukkan ke dalam alat umpan (termite baiting), lalu ditanam pada stasiun yang memiliki aktivitas rayap tertinggi.

c. Sampel uji pada alat pengumpanan diamati setiap 3 hari untuk mengetahui jumlah rayap yang menyerang umpan. Pengamatan dilakukan hingga eliminasi rayap mecapai $100 \%$.

d. Prosedur point $\mathrm{c}$ juga dilakukan pada umpan komersil (pembanding).

e. Pada akhir pengamatan dilakukan perhitungan persentase eliminasi rayap, baik pada umpan organik dan umpan komersil. 


\section{Variabel Pengamatan dan Analisis Data}

Variabel pengamatan pada penelitian ini adalah persentase jumlah rayap yang tereliminasi pada setiap pengamatan, dengan rumus sebagai berikut:

$E(\%)=\frac{P 1-P 2}{P 1} \times 100$

Dimana $\mathrm{E}$ adalah persentase eliminasi rayap, $\mathrm{P} 1$ adalah jumlah rayap pada pengamatan sebelumnya, P2 adalah jumlah rayap pada setiap pengamatan

Data yang diperoleh dianalisis secara deskiptif dan disajikan dengan menggunakan tabulasi ataupun grafik.

\section{HASIL DAN PEMBAHASAN}

\section{Karakteristik Umpan}

Umpan diproduksi dari limbah kayu pinus lapuk, limbah kertas, limbah kardus, dan daun kayu putih dengan komposisi masing-masing kayu pinus lapuk, limbah kertas, dan limbah kardus sebanyak 160 gram serta daun kayu putih kering 320 gram. Sebagai perekat digunakan tepung tapioka sebanyak 50 gram yang dilarutkan kedalam 500 $\mathrm{ml}$ air. Dengan komposisi tersebut ditargetkan dapat menghasilkan kerapatan 1,02 $\mathrm{g} / \mathrm{cm} 3$. Hasil pengukuran kerapatan diperoleh nilai $1,009 \mathrm{~g} / \mathrm{cm} 3$, dengan hasil dapat dilihat pada Gambar 2.

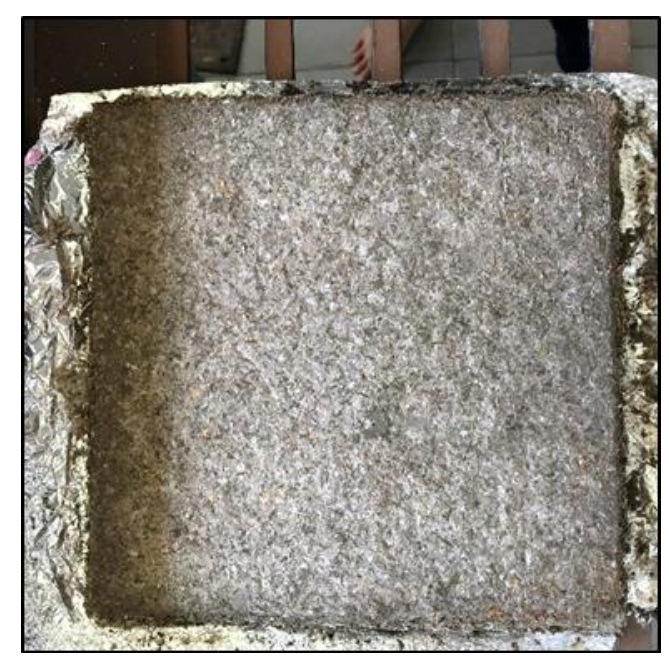

Gambar 2. Hasil produksi umpan organik

\section{Identifikasi Rayap}

Berdasarkan hasil pengamatan morfologi dan morfometri, menunjukkan bahwa rayap yang menyerang umpan adalah rayap Coptotermes sp. Rayap Coptotermes sp. termasuk dalam famili Rhinotermitidae dengan subfamili Coptotermitinae. Hal ini didasarkan pada kunci determinasi Sorrnuwat, dkk. (2004) dimana karakteristik rayap prajurit memiliki kepala yang berbentuk oval dengan bagian ujung kepala menyempit dan berwarna kekuningkuningan, dan fontanel berukuran besar pada kepala.
Karakter morfometrik dari rayap ini memiliki rata-rata panjang kepala tanpa mandibel 1,23-1,38 mm, lebar maksimum kepala 1,11-1,24 mm, lebar kepala pada dasar mandibel 0,62-0,75 mm. Panjang posmentum 0,66-0,90 $\mathrm{mm}$, lebar maksimum posmentum 0,37-0,41 mm, lebar minimum posmentum $0,18-, 020 \mathrm{~mm}$. Panjang dan lebar pronotum masing-masing $0,35-0,42 \mathrm{~mm}$ dan $0,73-0,81$ $\mathrm{mm}$. Panjang mandibel kiri 0,69-0,93 mm, memiliki jumlah antena 14 segmen. Bentuk rayap jenis ini dapat dilihat pada Gambar 3.

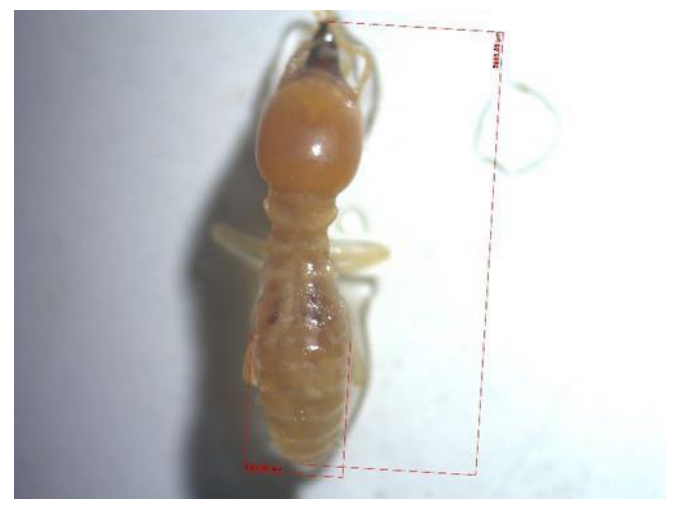

Gambar 3. Morfologi prajurit Coptotermes sp

\section{Eliminasi Rayap}

Fluktuasi kehadiran rayap pada umpan menunjukkan hasil dari awal hingga pertengahan periode pengamatan memiliki pola kehadiran rayap pada umpan yang relatif sama sebagaimana dapat dilihat pada Gambar 3. Hal tersebut dikarenakan masih stabilnya kondisi lingkungan maupun kondisi fisik umpan. Pola yang berbeda terjadi pada periode akhir pengamatan yang menunjukkan adanya perbedaan respon rayap terhadap keberadaan umpan.

Grafik pada Gambar 4 menunjukkan bahwa pada periode pengamatan pertama sampai dengan periode pengamatan ketujuh diperoleh hasil persentase yang tidak jauh berbeda antara kedua umpan tersebut. Apabila diperhatikan secara seksama, pada periode pengamatan kedua dan ketiga rayap telah mengalami eliminasi pada kedua umpan tersebut, sementara pada periode pengamatan keempat rayap terlihat mendatangi umpan kembali, lalu selanjutnya mengalami eliminasi lagi pada periode pengamatan kelima hingga periode pengamatan ketujuh. Akhirnya pada pengamatan kedelapan mulai terjadi perbedaan persentase fluktuasi kehadiran hingga mencapai eliminasi rayap 100\%. Pada Gambar 4 terlihat bahwa eliminasi rayap sebesar $100 \%$ pada umpan komersil terjadi pada periode pengamatan ke-11, sedangkan pada umpan organik terjadi pada periode pengamatan kesembilan. Fluktuasi yang terjadi pada akhir periode pengamatan dipengaruhi oleh kelembaban umpan utamanya pada umpan organik yang dapat dilihat pada Gambar 5, dimana pada periode pengamatan ketujuh sampai selanjutnya kelembaban umpan meningkat yang 
disebabkan karena sering terjadinya hujan di lokasi penelitian.

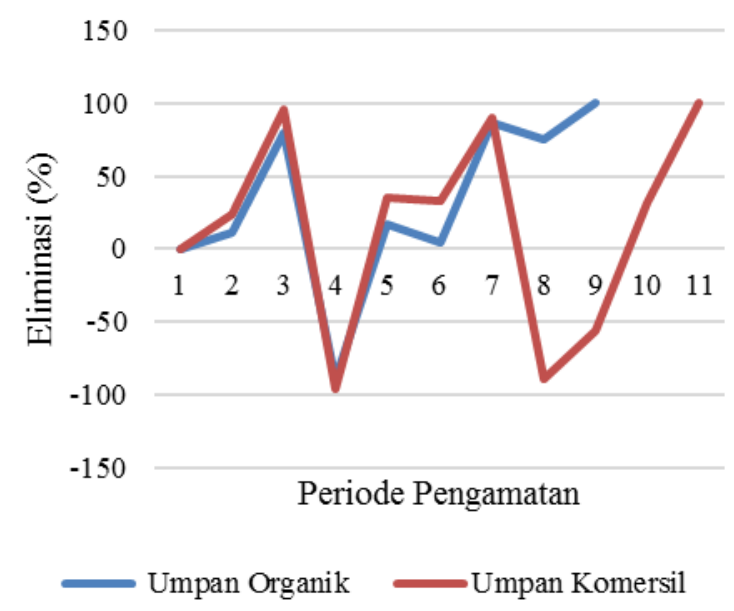

Gambar 4. Persentase fluktuasi kehadiran rayap pada umpan

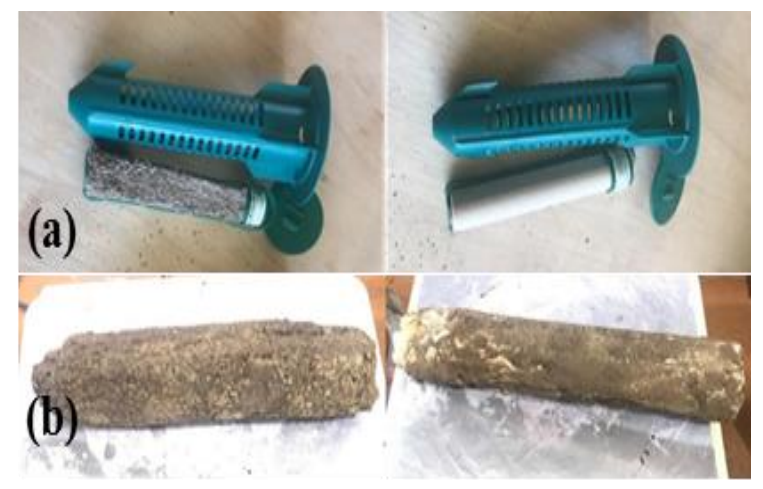

Gambar 5. Kondisi Umpan: (a) Kondisi umpan sebelum pengamatan; (b) Kondisi umpan setelah pengamatan.

Adanya pengaruh kelembaban terhadap efektivitas sampel sesuai dengan pernyataan Erli, dkk. (2015) bahwa kondisi lingkungan merupakan salah faktor yang mempengaruhi fluktuasi kehadiran rayap seperti suhu, kelembaban dan intensitas cahaya. Selain kelembaban, suhu juga merupakan salah satu faktor yang mempengaruhi kehadiran rayap. Sebagaimana yang dikemukakan French (1996) bahwa aktivitas makan rayap berbanding lurus dengan suhu, dimana apabila suhu menurun aktivitas makan rayap pun akan menurun. Sebaliknya pada suhu panas, aktivitas makan rayap akan meningkat.

Formulasi bahan yang ada pada umpan juga sangat mempengaruhi perbedaan dari persentase eliminasi dari kedua umpan tersebut. Sebagaimana yang dikemukakan Robertson dan Su (1995) bahwa hexaflumuron sangat sesuai sebagai bahan aktif umpan (makanan) rayap tanah dan mampu mengeliminasi koloni tersebut. Semua individu rayap yang telah mengkonsumsi bahan aktif tidak menunjukkan gejala keracunan dengan segera, tetapi mengganggu metabolisme pergantian kulit. Selanjutnya rayap tidak dapat membentuk khitin sebagai komponen struktural dari badan rayap sehingga beberapa hari kemudian mengalami kematian (Scheffrahn dan Su, 1991). Nandika (2014) melaporkan bahwa umpan rayap berbahan aktif hexaflumuron dapat menanggulangi serangan rayap pada suatu perkebunan kelapa sawit di Provinsi Riau dalam waktu empat sampai delapan minggu setelah pemaparan umpan dengan tingkat keberhasilan mencapai 85\%. Selain itu, Mahathir (2014) juga menunjukkan hasil penelitian bahwa ketermakanan formulasi umpan yang mengandung hexaflumuron oleh rayap tanah Coptotermes curvignathus lebih rendah daripada ketermakanan formulasi umpan yang berbahan kayu pinus.

\section{Palatabilitas Umpan}

Hasil penelitian menunjukkan adanya serangan yang nyata pada umpan yang ditempatkan di lapangan setelah 1 bulan 3 hari yang ditandai dengan kehilangan berat dari kedua umpan (palatabilitas). Persentase dari kedua umpan tersebut menunjukkan hasil bahwa persentase palatabilitas pada umpan organik lebih tinggi dibandingkan dengan persentase palatabilitas pada umpan komersil.

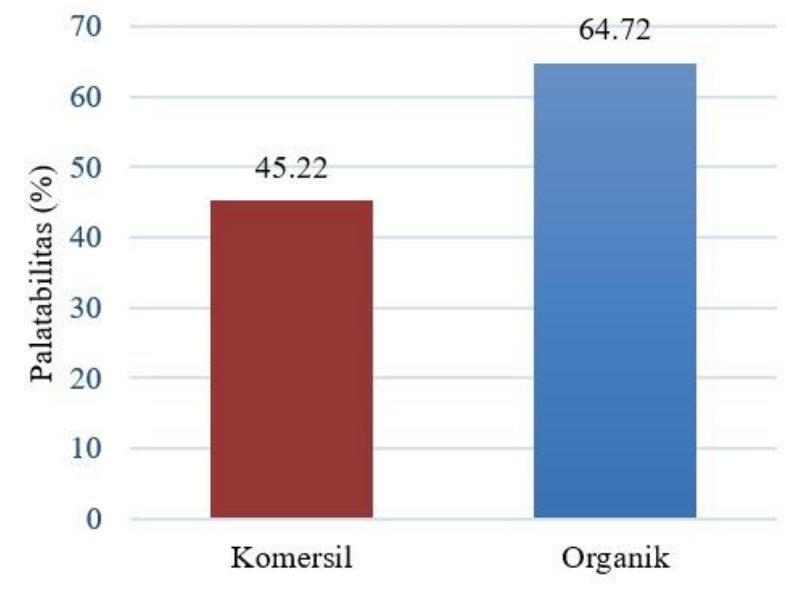

Gambar 6. Persentase palatabilitas umpan

Histogram pada Gambar 6 memperlihatkan perbedaan persentase yang cukup tinggi dari kedua umpan tersebut yaitu pada umpan organik menunjukkan hasil persentase sebesar $64,72 \%$, sedangkan pada umpan komersil menunjukkan hasil persentase sebesar $45,22 \%$. Hal tersebut menandakan tingkat kesukaan rayap terhadap kandungan yang ada pada daun kayu putih (Melaleuca leucadendron Linn.) yaitu eugenol yang dapat diturunkan ke beberapa senyawa diantaranya metil eugenol yang telah dikenal sebagai atraktan alami (Noviansari, dkk., 2013). Metil eugenol $\left(\mathrm{C}_{12} \mathrm{H}_{24} \mathrm{O}_{8}\right)$ adalah bahan semio chemicals, merupakan atraktan yang dapat merangsang organ olfactory sebagai alat sensor serangga (Kardinan, 2007). Hal tersebut juga diperkuat oleh penelitian Simbolon, dkk. (2015) bahwa jumlah rayap yang berpindah ke ekstrak daun kayu puth lebih banyak 
dibandingkan dengan daun lainnya, yaitu daun cengkeh (Syzygium aromaticum), daun kemangi (Ocimum sanctum L), daun kayu manis, (Cinnamomum burmannii) dan daun salam (Syzygium polyanthum Wight).

Terkait dengan keberadaan bahan termitisida dalam umpan, Mahathir (2014) juga mengemukakan bahwa formulasi umpan yang mengandung bahan hexaflumuron (umpan komersil) kurang disukai oleh rayap Coptotermes curvignathus dibandingkan dengan serbuk kayu pinus (umpan organik), mengingat kayu pinus merupakan kayu yang tergolong tidak awet (kelas awet IV) yang secara alami disukai oleh rayap tanah. Sebagaimana diketahui kayu pinus terdiri atas senyawa yang merupakan makanan utama rayap berupa fraksi karbohidrat (selulosa dan hemiselulosa) dan juga elemen kayu pinus berupa karbon $(50 \%)$, hidrogen $(6 \%)$, nitrogen $(0,04-0,10 \%)$ dan unsur lain dalam bentuk abu (0,20-0,50\%) (Padlinurjaji, 1995).

\section{KESIMPULAN}

Berdasarkan uraian dari hasil penelitian yang telah dilakukan, dapat ditarik kesimpulan bahwa:

1. Produksi umpan organik telah mencapai kerapatan yang ditargetkan, tetapi kerapatan umpan organik masih rendah dibandingkan dengan kerapatan umpan komersil.

2. Formulasi umpan komersil lebih efektif dalam mengeliminasi rayap Coptotermes sp. dibandingkan dengan formulasi umpan organik.

3. Tingkat kesukaan rayap lebih tinggi terhadap formulasi umpan organik dibandingkan dengan formulasi umpan komersil, dilihat dari persentase palatabilitas umpan organik lebih tinggi dibandingkan umpan komersil.

\section{DAFTAR PUSTAKA}

Djunaedy, A. (2007). Efektivitas teknik aplikasi agens hayati Heterorhabditis, (all strain) isolat lokal Madura terhadap pengendalian rayap tanah Macrotermes sp. di lapang. Skripsi Jurusan Budidaya Pertanian Fakultas Pertanian Trunojoyo, Madura. (Tidak Dipublikasikan).

Erli, Wardenaar, E., \& Muflihati. (2015). Uji aktivitas minyak atsiri daun salam (Syzigium polyanthum Walp) terhadap rayap tanah (Coptotermes curvignathus Holmgr). Jurnal Hutan Lestari, 3 (2).

French, J.R.J. (1996). Subterranean termite, Reticulitermes spp (Isoptera: Rhinotermitidae), colony response to baiting with hexaflumuron using prototype commercial termite baiting system. Journal of Entomological Science, 31, 143-151.
Grace, J.K., \& Su, N.Y. (2001). Evidence supporting the use of termite baiting system for long-term structural protection (Isopteran). Sociobiology, 37 (2), 301-310.

Indrayani, Y., Muin, M. ., \& Yoshimura, T. (2016). Crude extracts of two different leaf plant species and their responses against subterranean termite Coptotermes formosanus. Nusantara Bioscience, 8 (2), 226-231.

Kardinan, A. (2007). Tanaman pengusir dan pembasmi nyamuk vol. III. Jakarta: Agro Media Pustaka.

Mahathir, M. (2014). Efektifitas umpan rayap berbahan aktif hexaflumuron $0,5 \%$ dengan medium serbuk gergaji kayu pinus (Pinus Merkusii Jungh et de Vries). Skripsi pada Institut Pertanian Bogor (Tidak Dipublikasikan).

Muin, M., Arif, A., Nuraeni, S., \& Zohra, W.O.F. (2014). Formulasi umpan dari campuran kayu terdegradasi dan kertas limbah untuk pengendalian rayap. Jurnal IImu Teknologi Kayu Tropis, 13 (1), 61-69.

Nandika, D., Rismayadi, Y., \& Diba, F. (2003). Rayap: biologi dan pengendaliannya. Surakarta: Muhammadiyah University Press.

Lesmana, S. (2015, 10 Mei). Kerugian akibat serangan rayap capai Rp. 18,68 triliun. Diakses pada 29 November 2017 dari http://www.sainsindonesia.co.id/index.php/en/kabar-terkini/ 1528-kerugian-akibat-serangan-rayap-capai-rp-1868-triliun.

Noviansari, R., Sudarmin, \& Siadi, K.. (2013). Transformasi Metil Eugenol Menjadi 3-(3,4 Dimetoksi Fenil)-1-Propanol Dan Uji Aktivitasnya Sebagai Antibakteri. Jurnal Jurusan Kimia FMIPA, 2 (2), 114-118.

Padlinurjaji, I. (1995). Keterawetan kayu Pinus merkusii Jungh et de Vr. Dengan wolmanit CB dan bafilit CFK secara perendaman dan kemungkinan penerapannya. Disertasi pada Institut Pertanian Bogor.

Robertson, \& Su, N.Y. (1995). Discovery of an affective slow-acting insect growth regulator for controlling subterranean termites. Journal Down To Earth, 50 (1), 1-7.

Scheffrahn, R H., \& Su, N.Y. (1991). Laboratory evaluation of two slow acting toxicants against formosan and eastern subterranean termites (Isoptera: Rhinotermitidae). Journal of Economic Entomology, 84, 170-175.

Simbolon, R.I., Indrayani, Y., \& Husni, H. (2015). Efektifitas Bioatraktan Dari Lima Jenis Tanaman Terhadap Rayap Tanah (Coptotermes sp). Jurnal Hutan Lestari, 4 (1), 40-46.

Sornnuwat, Y., Vongkalung, C., \& Takematsu, Y. (2004). A systematic key to termites of Thailand. Kasetsart Journal, 38, 349-368.

Sucipto. (2009). Optimasi penggunaan $\mathrm{NaOH}$ dan tapioka pada produksi kertas seni dari pelepah pisang. Jurnal Teknologi Pertanian, 10 (1), 46-53.

Tambunan, B., \& Nandika, D. (1989). Deteriorasi kayu oleh faktor biologis. Bogor: Pusat Antar Universitas Bioteknologi, Institut Pertanian Bogor. 